\title{
$6: 30748736-30728886$
}

National Cancer Institute

\section{Source}

National Cancer Institute. 6: 30748736-30728886. NCI Thesaurus. Code C42123.

Physical location of DDX16_Gene 